\title{
THE USE OF EXTRACELLULAR AND INTRACELLULAR EMULSIFIERS FROM YEASTS IN ICE CREAM PRODUCTION
}

\author{
AMER, ABEER E. A. ${ }^{1}$, SOAD A. SHERIF ${ }^{1}$, I. M. ROUSHDY ${ }^{2}$ \\ AND M. N. I. EL-MAGDOUB ${ }^{2}$ \\ 1. Dairy Microbiology Department, Animal Production Research Institute, ARC, Dokki, \\ Giza \\ 2. Food Science Department, Faculty of Agriculture, Ain Shams University, Cairo
}

(Manuscript received 13 December 2008)

\begin{abstract}
The main objective of this study was to manufacture ice cream using different ratios of extracellular bioemulsifiers, which was produced by Candida utilis EMCC 120 and intracellular bioemulsifiers produced by Saccharomyces cervisiae EMCC 69. The results showed that using extracellular bioemulsifiers had slightly effect on increasing of the specific gravity and weight per gallon in the resultant ice cream, there were a slightly bioemulsifiers samples decreases in specific gravity and weight per gallon and increase in the overrun with intracellular. In addition, Extracellular bioemulsifiers reduced the rate of melting comparing to intracellular samples. Generally using of extracellular bioemulsifiers in the manufacture of ice cream improves whipping quality of the mix and gave smoother body and texture. The preferable concentration of bioemulsifiers produced by $S$. cereviciae EMCC 69 or C. utilis EMCC 120 was $0.2 \%$ which enhanced viscosity, freezing point and overrun, and eventually more acceptable to consumers was gained.
\end{abstract}

Key words: Yeast, extracellular emulsifier, intracellular emulsifier, ice cream.

\section{INTRODUCTION}

Emulsifiers play very important roles in the structure and quality of ice cream. Emulsifiers have been used in ice cream mix manufacture for many years. They are usually integrated with the stabilizers in proprietary blends but their functions and action differ remarkably from stabilizers. They are used to promote nucleation of fat during aging, thus reducing aging time will improve the whipping quality of the mix that is due to their function at the air interface, resulting in reducing air sizes and homogeneous distribution of air in the ice cream, produce a dry stiff ice cream as they enhance fat destabilization, facilitating modling, fancy extrusion, and sandwich manufacture. It will also increase resistance to shrinkage and rapid melt down. Increase resistance to the development of coarse icy textures. Due to the effect of fat 
agglomerates, more numerous bubbles, thinner lamellae between adjacent air bubbles on size and growth of ice crystals. It will provide smooth texture in the finished product, due to fat structuring and interaction of fat agglomerates with the mouth during consumption. (Marshall et al., 2003). The types of emulsifiers permitted and the levels at which they may be used in ice cream and frozen products are regulated by local food regulations. One of these types is sucrose fatty acid esters (Ryoto sugar ester) consisting of sucrose as hydrophilic group and fatty acid as lipophilic group they have a large emulsifying capacity.

On the other hand extracellular and intracellular emulsifiers have a number of advantages over the other sources of emulsifier (biological, chemical or synthetic) because of their biodegradable, nature effectiveness wide range of $\mathrm{pH}$, temperature and osmotic pressure. We have used a yeast strains Candida utilis EMCC 120 and Saccharomyces cervisiae EMCC 69 were usedto produce a food grade extracellular and intracellular bioemulsifiers. Therefore, the aim of this work was to study the behavior of this new extracellular and intracellular bioemulsifiers on ice cream production.

\section{MATERIALS AND METHODS}

\section{Material}

Fresh whole buffalo's milk $6 \%$ fat was obtained from the herd of the Dairy cattle of the Faculty of Agriculture, Ain Shams University.

Low heat skim milk powder (SMP) made in Holland wasobtained from the local market of Cairo.

Commercial grade granulated cane sugar produced by Sugar and Integrated Industries Co. at Hawamdia was obtained from the local market.

Sodium Carboxy methylcellulose (CMC), made by BDH Chemicals LTD. poole, England, was obtained from DTE company.

Vanilla (Chem. Rein 100\%) made by Boehringer Manheim GMB, Germany was obtained from the local market. Emulsifier mono-glyceride (Glycerol monoleate) (GMO) was obtained from the local market.

Chemicals used in this study were of the analytical grade. Microbiological media:

the following media were obtained from Oxoid Division of Oxoid LTD, London: Violet Red Bile agar (V.R.B.A.), Trypton soya agar (T.S.A.), yeast extract peptone agar (Y.E.P.A.), S.S. agar and Baird parker's agar. 


\section{Yeast Strains}

Eleven yeast strains were used in this study. Eleven yeast strains were used in this study. Candida utilis NCYC 769 (EMCC 120), Candida kefyr NCYC 744 (EMCC 68), Creptococcus marinus NCYC 784 (EMCC 121), and Pichia anomala NCYC 20 (EMCC 121) (National Collection of Yeast Cultures, Research Park Colney, Norwich NR4 7UA, U.K.) Saccharomyces cerevisiae ATCC 287 (EMCC 69), Saccharomyces cerevisiae ATCC 4126 (EMCC 71), and Candida bombicola ATCC 22214 (EMCC 91). Candida utilis NRRL Y-900 (EMCC 41). Candida tropicalis DSM 70156 (EMCC 2) (Deutsche Sammlung von Mikroorganismen, Germany). All strains were kindly obtained from the Egyptian Microbial Culture Collection, Cairo MIRCEN, Faculty of Agriculture, Ain Shams University, Cairo, Egypt

Commercial two strains of baker's yeast (Saccharomyces cerevisiae) were obtained from the local market.

\section{Extracellular and intracellular bioemulsifiers were produced as follows}

\section{Fermentation medium}

The fermentation medium is a Modified Czapek's yeast broth.

\section{Fermentation Process}

Erlenmeyer flasks (500 ml) containing $100 \mathrm{ml}$ of Modified Czapek's yeast broth were inoculated with $2 \%$ of $24 \mathrm{~h}$ active culture and incubated for 3 days at $25^{\circ} \mathrm{C}$ in a shaking water bath with agitation at $200 \mathrm{rpm}$ for $60 \mathrm{~h}$.

Two strains of yeasts Candida utilis EMCC 120 and Saccharomyces cerevisiae EMCC 69were tested on one liter Modular fermentor (Mini Bioreactor, A. Gallen Kamp \& Co. Ltd.) operated at $25^{\circ} \mathrm{C}$ and $500 \mathrm{rpm}$ for Candida utilis EMCC 120 and at $28^{\circ} \mathrm{C}$ and $300 \mathrm{rpm}$ for examining the strains ability to produce significant amounts of the emulsifying agent.

\section{Emulsifier extraction}

The intracellular emulsifying agent was extracted from cells crop by heat extraction procedure of Cameron et al., (1988). The extracellular bioemulsifier was extracted from cell free extract as recirculate over modified cellulose ultrafiltration disc with magnetic sterrier, filters with a cut-off of 10000 Dalton to collect the extracellular yield with a molecular mass over 5000 Dalton. Cells crop will be collected by centrifugation, at $5000 \mathrm{xg}$ for $20 \mathrm{~min}$ at $4{ }^{\circ} \mathrm{C}$. The retentate was used as extracellular bioemulsifier.

\section{2- Manufacture of ice Cream}

The following procedure for ice cream making was manufacturig. Seven ice cream mixes ( $2 \mathrm{~kg}$ each), each of three replicates, were prepared. All mixes were standardized to contain $8 \%$ fat, $11 \%$ solids not fat (SNF), $12 \%$ sucrose $0.2 \%$ carboxy 
methyl cellulose and $0.05 \%$ vanilla as a stabilizer. In each treatment, mix ingredients were heated at $80{ }^{\circ} \mathrm{C}$ for $30 \mathrm{sec}$ as suggested by Rothwell (1976). The mix was divided into 7 portion, the first was processed as control and was manufactured using $0.2 \%$ Glycerol monoleate (a commerical emulsifier) The other portions were processed using extracellular bioemulsifier was added at levels of $0.05,0.1$ and $0.2 \%$, and intracellular bioemulsifiers was added at levels of $0.05,0.1$ and $0.2 \%$ respectively. All mixes were cooled to $5^{\circ} \mathrm{C}$ and aged overnight at the same temperature.

\section{Methods of analysis}

The following parameters were determined in the mix of ice cream:

\section{Bacteriological analyses:}

Total plate count, coliform group count, E. coli count, Salmonella spp. count, Staphylococcus spp. count were determined according to the method described by the A.O.A.C. (1994).

\section{Chemical analyses:}

Dry matter (DM) content was determined according to A.O.A.C. (1994). Fat content was determined according to A.O.A.C. (1994). Protein content (Total nitrogen $\times$ 6.38) was determined in ice cream mix according to AOAC (1994). The $\mathrm{pH}$ value was determined electrometrically using glass electrode $\mathrm{pH}$ meter 7010 Electronic Instruments Limited. The titratable acidity of the ice cream mixes was estimated according to Ling (1963). The method of Pearson (1973) was applied to determine the ash content.

\section{Physical analyses:}

Mix volumes were calculated and weight of ice cream mixes were measured at $5{ }^{\circ} \mathrm{C}$. Results are the average of three replicates. The viscosity of ice cream mix was determined according to Bourne (1982) using Hopppler viscometer Type BH No. 9367 at $20^{\circ} \mathrm{C}$.

Freezing point was measured as described by Arbuckle (1986) using an electronic thermometer precision Modeled 15th, Kreuzwertheim, Germany. Specific gravity was determined according to Winston (1958). The weight per gallon of both mixes and frozen ice cream in pounds was directly calculated according to Arbuckle (1986) by multiplying the specific gravity of the mix by the factor 8.34 (the weight per gallon of water in pounds) and melting resistance of the resultant ice cream was determined as described by Arbuckle (1986).

\section{The following parameters were determined in ice cream}

Ice cream overrun was determined on samples stored at -26 by the following equation:

Overrun $\%=100 \times($ ice cream volume - mix volume $) \times(\text { mix volume })^{-1}$ 


\section{Sensory evaluation:}

The different ice cream treatment were organoleptically evaluated for different treatments were carried out according to Arbuckle (1986), for flavor (50 points), body and texture (40 points), and 10 points for melting quality (100 total score) by 20 panelists of the experienced staff members of the dairy Science Department, Faculty of Agriculture, Ain Shams University.

\section{RESULTS AND DISCUSSION}

\section{Chemical properties of ice cream mixes}

It could be noticed From the that the data of Table (1) that the of average dry matter of ice cream mixes with or without addition of extracellular bioemulsifiers from C. utilis EMCC 120 by $0.05,0.1$ and $0.2 \%$ were $36.74,36.72$ and $36.73 \%$ respectively which nearly to be similarly to control .

\section{Fat content:}

Table (1) shows that fat content in all ice cream mix samples including control was in narrow figures and ranged between 8.0 to $8.03 \%$ in all mix samples. The very slight difference in fat values is due to the experimental error since the fat was adjusted in all mix samples during preparation to be $8 \%$.

As regards protein content of ice cream. From the results presented in Table (1), indicate that the whole replacement of commercial emulsifier with either intracellular bioemulsifier from $S$. cereviciae EMCC 69 or extracellular bioemulsifier from C. utilis EMCC 120 has no effect on protein contents of ice cream mix.

\section{Ash content:}

The replacement of intracellular and extracellular bioemulsifiers was associated has no effect in the ash content of ice cream mixes.

\section{Titratable acidity and pH:}

The replacement intracellular and extracellular bioemulsifiers in the ice cream mix did not lead to any changes in the $\mathrm{pH}$ values which were nearly similar to that of the control. 
Table 1. Chemical composition of ice cream mixes with different levels of intracellular (Saccharomyces cervisiae EMCC 69) and extracellular (candida utilis EMCC 120) bioemulsifiers.

\begin{tabular}{|l|c|c|c|c|c|c|c|}
\hline & Control & \multicolumn{3}{|c|}{ Intracellular bioemulsifiers \% } & \multicolumn{3}{c|}{ Extracellular bioemulsifiers \% } \\
\hline & $\begin{array}{l}0.2 \% \\
* \mathrm{GMO}\end{array}$ & 0.05 & 0.1 & 0.2 & 0.05 & 0.1 & 0.2 \\
\hline Dry matter \% & 36.69 & 36.75 & 36.76 & 36.74 & 36.74 & 36.72 & 36.73 \\
\hline Fat \% & 8.00 & 8.02 & 8.03 & 8.01 & 8.01 & 8.00 & 8.00 \\
\hline $\begin{array}{l}\text { Protein \% } \\
(\text { T.N } \times 6.38)\end{array}$ & 9.54 & 9.50 & 9.53 & 9.52 & 9.54 & 9.55 & 9.53 \\
\hline Ash \% & 1.10 & 1.10 & 1.08 & 1.09 & 1.06 & 1.10 & 1.11 \\
\hline pH value & 6.42 & 6.45 & 6.45 & 6.41 & 6.45 & 6.45 & 6.45 \\
\hline Titratable acidity \% & 0.69 & 0.68 & 0.67 & 0.68 & 0.67 & 0.67 & 0.67 \\
\hline
\end{tabular}

*GMO: (glecerol monoolate).

\section{Physical properties of ice cream mixes}

\section{Specific gravity and weight per gallon:}

Physical properties of ice cream mixes with different levels of intracellular produced by Saccharomyces cervisiae EMCC 69 or extracellular bioemulsifiers produced by $c$. utilis EMCC 120 are presented in Table (2). The specific gravity of control mix was 1.0817 while it was $1.0834,1.0706$ and 1.0752 for mixes with 0.05 , 0.1 and 0.2 of intracellular bioemulsifier. Mixes with the same ratios of extracellular bioemulsifier had specific gravity. values of $1.0804,1.0773$ and $1.0826 \mathrm{~g} \mathrm{~cm}^{-3}$. The forementioned values indicated that the addition of bioemulsifiers has no effect on the specific gravity values of mixes. Weight per gallon of ice cream mixes showed the same trend as specific gravity since it was calculated with specific gravity values. Weight per gallon of ice cream mixes was, 9.026, 9.124, 8.934, 8.972, 9.015, 8.906 and 9.034pounds for control and treatments with $0.05,0.1$ and 0.2 of intracellular and extracellular bioemulsifier respectively.

\section{Freezing point:}

Freezing point of ice cream mixes with different levels of intracellular or extracellular bioemulsifiers are also presented in Table (2). These results might be due to the changes in the ratio of free and bound water in the mix system indirectly resulted by the action of intracellular and extracellular bioemulsifier added.

\section{Viscosity:}

Apparent viscosity values of treatments reported in Table (2). Among treatments with bioemulsifier the apparent viscosity values increased by increasing the ratio added of bioemulsifier to the mix led to a highest increase in mix viscosity (Table 2). It 
could be noticed that among all ice cream mixs the treatment with $0.2 \%$ of extracellular bioemulsifier showed the highest viscosity. Viscosity increased proportionally by increasing of new intracellular or extracellular bioemulsifier ratios. These result might be due to the composition and low acid effect of new intracellular and extracellular bioemulsifiers. These results might be due to the composition of intracellular and extracellular bioemulsifiers. However, it is well known that the ice cream mix viscosity is greatly affected by changes in the stabilizer kind and level than the emulsifier.

Table 2. Physical properties of different levels of intracellular (Saccharomyces cervisiae EMCC 69) and extracellular (candida utilis EMCC 120) bioemulsifiers.

\begin{tabular}{|c|c|c|c|c|c|c|c|}
\hline \multirow{2}{*}{ Property } & \multirow{2}{*}{$\begin{array}{c}\text { Control } \\
0.2 \% \\
\text { *GMO }^{2}\end{array}$} & \multicolumn{3}{|c|}{ Intracellular bioemulsifiers \% } & \multicolumn{3}{|c|}{ Extracellular bioemulsifiers \% } \\
\hline & & 0.05 & 0.1 & 0.2 & 0.05 & 0.1 & 0.2 \\
\hline Specific gravity & 1.0817 & 1.0814 & 1.0706 & 1.0752 & 1.0804 & 1.0804 & 1.0826 \\
\hline $\begin{array}{l}\text { Weight per gallon } \\
\text { (pound) }\end{array}$ & 9.026 & 9.024 & 8.934 & 8.972 & 9.015 & 9.015 & 9.034 \\
\hline Freezing point $\left({ }^{\circ} \mathrm{C}\right)$ & -2.01 & -2.05 & -2.03 & -2.02 & -2.02 & -2.03 & -2.04 \\
\hline Viscosity (c.p.) & 92.7 & 245.6 & 253.9 & 260.5 & 365.5 & 366.0 & 375.0 \\
\hline
\end{tabular}

*GMO: (glecerol monoolate).

\section{Resultant ice cream Properties}

\section{Physical properties:}

Physical properties of resultant ice cream with different levels of intracellular bioemulsifiers produced by Saccharomyces cervisiae EMCC 69 or extracellular bioemulsifiers produced by $c$. utilis EMCC 120 are presented in Table (3). Ice cream with the same ratios of extracellular bioemulsifier had specific gravity values of 0.7761 , 0.7784 and 0.7874 . The forementioned values indicated that the added bioemulsifier has no effect on the specific gravity values of ice cream. Weight per gallon of ice cream mixes was in the same trend as specific gravity since it was calculated of specific gravity values. Weight per gallon of ice cream was $6.651,6.571,6.580,6.495,6.476,6.621$ and 6.570 for control and treatments with $0.05,0.1$ and 0.2 of intracellular and extracellular bioemulsifier respectively.

\section{Overrun:}

Overrun values of treatments reported in Table (3), they were 61.94, 62.98, 67.79, 74.61, 65.91, 71 and $78.90 \%$ for control and treatments with $0.05,0.1$ and 0.2 of intracellular and extracellular bioemulsifier respectively. From the data 
presented it can be seen that the control sample with $0.2 \%$ glecerol monoolate had lower overrun value than that with intracellular or extracellular bioemulsifier. The results also indicated that the samples with extracellular bioemulsifier possessed higher overrun values than that of intracellular bioemulsifier.

\section{Melting resistance:}

Table (3) shows the effect of adding intracellular or extracellular bioemulsifier on the melting resistance of ice cream. Among treatments with bioemulsifier the melting resistance of ice cream proportionally increased with increasing ratio of intracellular or extracellular bioemulsifier added led to a highest increase in melting resistance of ice cream (Table 3). It could be noticed that among all ice cream the treatment with $0.2 \%$ of extracellular bioemulsifier showed the highest melting resistance of ice cream. melting resistance of ice cream increased proportionally by increasing of new intracellular or extracellular bioemulsifier ratios.

Table 3. Physical properties of ice cream with different levels of intracellular (Saccharomyces cervisiae EMCC 69) and extracellular (candida utilis EMCC 120) bioemulsifiers .

\begin{tabular}{|c|c|c|c|c|c|c|c|}
\hline \multirow[t]{2}{*}{ Property } & Control & \multicolumn{3}{|c|}{ Intracellular bioemulsifiers \% } & \multicolumn{3}{|c|}{ Extracellular bioemulsifiers \% } \\
\hline & $0.2 \% * \mathrm{GMO}$ & 0.05 & 0.1 & 0.2 & 0.05 & 0.1 & 0.2 \\
\hline Specific gravity & 0.7971 & 0.7875 & 0.7886 & 0.7784 & 0.7761 & 0.7784 & 0.7874 \\
\hline Weight per gallon & 6.651 & 6.571 & 6.580 & 6.495 & 6.495 & 6.495 & 6.570 \\
\hline Overrun \% & 61.94 & 62.98 & 67.79 & 74.61 & 65.91 & 71 & 78.90 \\
\hline Melting $\% \quad$ after & & & & & & & \\
\hline $15 \mathrm{~min}$ & 3.69 & 13.81 & 7.13 & 4.44 & 5.36 & 4.27 & 9.66 \\
\hline $30 \mathrm{~min}$ & 19.62 & 52.24 & 33.08 & 20.82 & 23.78 & 21.00 & 41.00 \\
\hline $45 \mathrm{~min}$ & 66.75 & 86.91 & 73.79 & 68.44 & 75.76 & 73.57 & 71.21 \\
\hline $60 \mathrm{~min}$ & 78.51 & 88.00 & 76.80 & 73.45 & 77.80 & 76.90 & 78.35 \\
\hline $75 \mathrm{~min}$ & 98.89 & 98.50 & 98.98 & 98.75 & 98.70 & 98.78 & 98.85 \\
\hline
\end{tabular}

*GMO: (glecerol monoolate).

\section{Organoleptic properties of ice cream \$}

The average sensory score points of different ice cream treatments manufactured with adding intracellular and extracellular bioemulsifiers are showing in Table (4). It is obvioused that the control sample had total score of 97 points. However, the ice cream containing $0.05,0.1$ and $0.2 \%$ intracellular and extracellular bioemulsifiers possessed total score points of 95, 98.2, 99.6, 97.5, 98.9 and 99.4 
respectivly. These data indicated that addition of intracellular and extracellular bioemulsifiers to ice cream mixes, at the concentration of $0.05,0.1$ and $0.2 \%$ enhanced the quality of resulting ice cream. These results are in accordance with those of Marshal et $a I_{v / n}$ (2003) who concluded that low level of emulsifier added as emulsifying agent achieved satisfactory physical and sensory properties in the resulting ice cream.

Table 4. Organoleptic scores of resultant ice cream with different intracellular (Saccharomyces cervisiae EMCC 69) and extracellular (candida utilis EMCC 120) bioemulsifiers .

\begin{tabular}{|c|c|c|c|c|c|c|c|}
\hline \multirow{2}{*|}{ Property } & Control & \multicolumn{3}{|c|}{ Intracellular bioemulsifiers } & \multicolumn{3}{c|}{ Extracellular bioemulsifiers } \\
$\%$
\end{tabular}

*GMO: (glecerol monoolate).

\section{Bacteriological quality of ice cream:}

The bacteriological examinations of ice cream made with different levels of intracellular and extracellular bioemulsifiers. Results in Table (5) indicated that addition of intracellular and extracellular bioemulsifiers to the ice cream mixes had no effect on the total viable count of the resulting ice cream. It could be observed from the obtained results that the highest total bacterial count was $53.5 \times 10^{3} \mathrm{cfu} / \mathrm{g}$ in the sample with $0.05 \%$ intracellular bioemulsifier produced by $S$. ceerviciae EMCC 69 compared with $30 \times 10^{3} \mathrm{cfu} / \mathrm{g}$ in the control. Staphylococcus count, Coliform count, Echerichia coli count, Sallmonella species were not be detected in any of ice cream samples. 
Table 5. The microbial contents of resultant ice cream affected by the percentages of intracellular and exracellular bioemulsifier from candida utilis EMCC 120 and Saccharomyces cerevisiae EMCC 69.

\begin{tabular}{|c|c|c|c|c|c|c|c|}
\hline \multicolumn{7}{|c|}{ Level of Intracellular and extracellular bioemulsifiers } \\
\hline \multicolumn{2}{|c|}{$\%$ of Intracellular bioemulsifiers } & \multicolumn{3}{c|}{ c. utilis EMCC extracellular bioemulsifiers } \\
\hline Yeast strain & Control & \multicolumn{3}{|c|}{ S. cereviciae EMCC 69} & \\
\hline & & 0.05 & 0.1 & 0.2 & 0.05 & 0.1 & 0.2 \\
\hline Total Count $\times 10^{3}$ & 30 & 53.5 & 35 & 40 & 48.5 & 32.1 & 45.5 \\
\hline Staph. ${ }^{\text {C Count } \times 10}$ & NC ${ }^{\text {d }}$ & NC & NC & NC & NC & NC & NC \\
\hline E.coli ${ }^{\text {b }}$ Count $\times 10$ & NC & NC & NC & NC & NC & NC & NC \\
\hline Sallmo. ${ }^{c}$ Count $\times 10$ & NC & NC & NC & NC & NC & NC & NC \\
\hline Coliform Count $\times 10$ & NC & NC & NC & NC & NC & NC & NC \\
\hline
\end{tabular}
a) Staph. = Staphylococcus spp.
b) $\mathrm{E}$.coli $=$ Echerichia coli.
c) Sallmo. = Sallmonella spp.
d) $\mathrm{NC}=$ No colony

\section{REFERENCES}

1. AOAC 1994. Association of Official Analytical Chemists official Methods of Analysis. Washington, P. C., USA.

2. Arbuckle, W. S. 1986. Ice Cream. $4^{\text {th }}$ ed, The AVI Publishing Company, Inc

3. Westport, Connecticut, U.S.A .

4. Bourne, M. C. 1982. "Food texture and viscosity concept and Measurement". Academic Press Inc., New York, USA, p.p. 240-244.

5. Cameron, D. R., D. G. Cooper and R. J. Neufeld. 1988. The mannoprotein of Saccharomyces cerevisiae is an effective bioemulsifier. American Society for microbiology. 54: (6), 1420-1425.

6. Ling, E. R. 1963. ' A Text Book of Dairy Chemistry". Vol. 2. Practical $3^{\text {rd }}$ Ed. Chapman and Hall. Ltd London, UK.

7. Marshall, R. T., H. D. Goff and R. W. Hartel. 2003. Ice Cream $6^{\text {th }}$ ed Kluwer Academic/ Plenum Puplishers, New York.

8. Pearson, D. 1973. In Laboratory Techniques in food Analysis. 1 st Ed. Butterworths, Boston. pp. 48-69.

9. Rothwell, J. 1976. Ice cream, its present day manufacture and some problems. J. Society Dairy Tech. 22 (3) 161-166.

10. Winston, A. L. 1958. "Analysis of foods" $3^{\text {rd }}$ Ed. John Wiley and sons. Inc., New York, USA p. 6. 


\section{إستخدام مواد الاستحلاب الخارجية و الاخلية من الخمائر في إنتاج الأيس كريم}

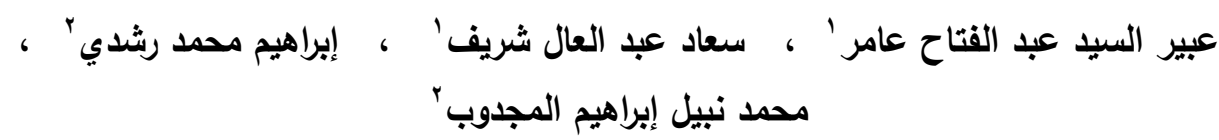
ا - قسم المبكروبيولوجى - معه بحوث الإنتاج الحيوانسى مركز البحوث الزراعية - الدقى r - قسم علوم الأغذبة - كلبة الزراعة - جامعة عين شهس - شبرا الخبية - القاهة

Modified Czapek,s yeast broth تهدف هذه الدراسة إلى تتمية سلالتين من الخميرة في بيئة سلالة الخميرة Saccharomyces cerevisiae EMCC 69 المنتجة لمادة الاستحلاب الداخلية و سلالة سلة الخميرة Candida utilis EMCC 120 طريق الترشيح الدقيق ( الفائق) Ultra Filtration وتم استخدام مادة الاستحلاب الداخلية أوالخارجية

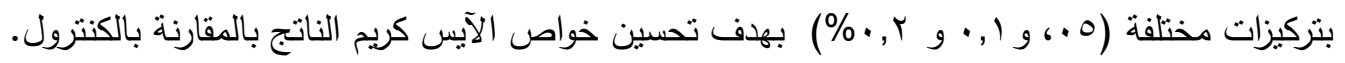

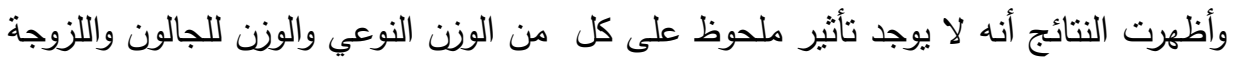

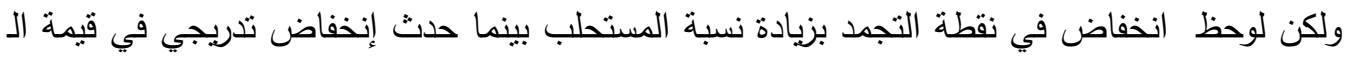

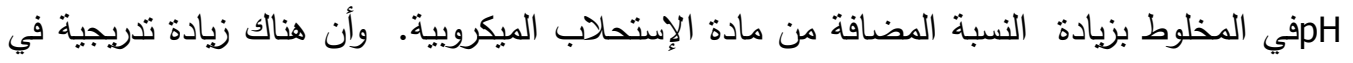
الريع ونقص في سرعة الإنصهار خاصة خلال النصف ساعة الأولى في الايس كريم (المجمد) بإضافة مادة الإستحلاب الميكروبية. أما من حيث الخواص الحسية متضمنة النكهة والقوام والتركيب وجودة الإني

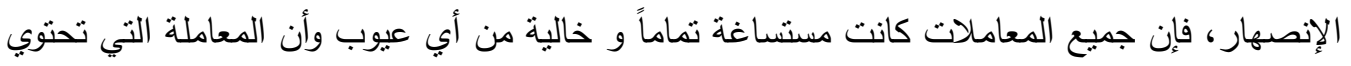
على مادة إستحلاب ميكروبية بنسبة r,••\% حصلت على أعلى درجات التحكيم مقارنة بالمخلوط المحتوي على المستحلب التجاري. وقد أظهرت النتائج المتحصل عليها أن استخدام مادة الاستحلاب المنتجة بواسطة سلالة الخميرة Candida utilis EMCC أو المنتجة بواسطة سلالة الخميرة Saccharomyces cerevisiae EMCC 69 120 بتركيز r, \% أعطى نتائج جيدة من حيث اللزوجة ونقطة التجمد كما عمل على زيادة نسبة الريع والقابلية للخفق وانعكس هذا على خواص الانصهار عند التحكيم الحسي مما ادى غلى الحصول على هنى أفضل درجات التحكيم. 